\title{
Nutrient availability induces community shifts in seagrass meadows grazed by turtles
}

\author{
Isis Gabriela Martínez López ${ }^{\text {Corresp., } 1,2}$, Marloes van den Akker ${ }^{3}$, Liene Walk ${ }^{3}$, Marieke M van Katwijk ${ }^{3}$, Tjisse van \\ der Heide ${ }^{3}$, Brigitta Ine van Tussenbroek ${ }^{1}$ \\ 1 Instituto de Ciencias del Mar y Limnología/ Unidad Académica de Sistemas Arrecifales-Puerto Morelos, Universidad Nacional Autónoma de México, Puerto \\ Morelos, Quintana Roo, Mexico \\ 2 Posgrado en Ciencias del Mar y Limnología, Universidad Nacional Autónoma de México, Ciudad de México, Ciudad de México, Mexico \\ 3 Institute for Water and Wetland Research, Radboud University, Nijmegen, The Netherlands \\ Corresponding Author: Isis Gabriela Martínez López \\ Email address: igml_2015@comunidad.unam.mx
}

In the Caribbean, green turtles graze seagrass meadows dominated by Thalassia testudinum through rotational grazing, resulting in the creation of grazed and recovering (abandoned) patches surrounded by ungrazed seagrasses. We evaluated the seagrass community and its environment along a turtle grazing gradient; with the duration of (simulated) grazing as a proxy for the level of grazing pressure. The grazing levels consisted of Short-term (4 months clipping), Medium-term (8 months clipping), Long-term grazing (8 months of clipping in previously grazed areas), 8-months recovery of previously grazed patches, and ungrazed or unclipped patches as controls. We measured biomass and density of the seagrasses and rhizophytic algae, and changes in sediment parameters. Medium- and Long-term grazing promoted a shift in community species composition. At increasing grazing pressure, the total biomass of $T$. testudinum declined, whereas that of early-successional increased. Ammonium concentrations were highest in the patches of Medium-term $(9.23+0.78 \mu \mathrm{M})$ and Long-term grazing levels $(10.96+2.16 \mu \mathrm{M})$ and were lowest in the control areas $(4.65+1.48 \mu \mathrm{M})$. $T$. testudinum is a late-successional species that maintains sediment nutrient concentrations at levels below the requirements of earlysuccessional species when dominant. When the abundance of this species declines due to grazing, these resources become available, likely driving a shift in community composition towards a higher abundance of early-successional species. 
1 Nutrient availability induces community shifts in seagrass meadows grazed by turtles

2

3

4 Isis Gabriela Martínez López ${ }^{1,2}$, Marloes van den Akker ${ }^{3}$, Liene Walk³, Marieke M. van Katwijk

$5 \quad{ }^{3}$ Tjisse van der Heide ${ }^{3}$ Brigitta I. van Tussenbroek ${ }^{1}$

6

$7 \quad{ }^{1}$ Unidad Académica de Sistemas Arrecifales-Puerto Morelos, Instituto de Ciencias del Mar y

8 Limnología, Universidad Nacional Autónoma de México, Cancún, Quintana Roo,

9 2Posgrado en Ciencias del Mary Limnología, Universidad Nacional Autónoma de México; Coy

10 oacán, Ciudad de México, México México.

11 3nstitute for Water and Wetland Research, Radboud Universiteit Nijmegen, The Netherlands.

12 Corresponding Author:

13 Isis Gabriela Martínez López ${ }^{1}$

14 Av. Ciudad Universitaria 3000, Coyoacán, Ciudad de México, C.P. 04510, México.

15 Email address: igml_2015@comunidad.unam.mx 
23 ABSTRACT

24 In the Caribbean, green turtles graze seagrass meadows dominated by Thalassia testudinum

25 through rotational grazing, resulting in the creation of grazed and recovering (abandoned)

26 patches surrounded by ungrazed seagrasses. We evaluated the seagrass community and its

27 environment along a turtle grazing gradient; with the duration of (simulated) grazing as a proxy

28 for the level of grazing pressure. The grazing levels consisted of Short-term (4 months clipping),

29 Medium-term (8 months clipping), Long-term grazing (8 months of clipping in previously

30 grazed areas), 8-months recovery of previously grazed patches, and ungrazed or unclipped

31 patches as controls. We measured biomass and density of the seagrasses and rhizophytic algae,

32 and changes in sediment parameters. Medium- and Long-term grazing promoted a shift in community species composition. At increasing grazing pressure, the total biomass of $T$. testudinum declined, whereas that of early-successional increased. Ammonium concentrations were highest in the patches of Medium-term $(9.23 \pm 0.8 \mu \mathrm{M})$ and Long-term grazing levels $(10.96 \pm 2.2 \mu \mathrm{M})$ and were lowest in the control areas $(4.65 \pm 1.5 \mu \mathrm{M})$. T. testudinum is a latesuccessional species that maintains sediment nutrient concentrations at levels below the requirements of early-successional species when dominant. When the abundance of this species declines due to grazing, these resources become available, likely driving a shift in community composition towards a higher abundance of early-successional species. 


\section{INTRODUCTION}

Changes in the species composition of seagrass communities have been primarily attributed to bottom-up control mechanisms, such as resource availability (Touchette \& Burkholder 2000; Ralph et al. 2007), with top-down mechanisms, such as herbivory, only playing a minor role. The drastic declines of large herbivores, like green turtles, manatees, and dugongs, caused by human overexploitation (Jackson 1997; Jackson 2001; Hughes et al. 2004; Valentine \& Duffy 2006) has contributed to the undervaluation of top-down controls in seagrass communities. In recent decades, conservation strategies have led to local increases in abundance of green turtles (Chelonia mydas), with noticeable impacts of turtle grazing on seagrass communities (Zieman 1984; Kaladharan et al. 2013; Kelkar et al. 2013; Molina-Hernández \& van Tussenbroek 2014). Herbivores, particularly large herbivores such as green turtles, can alter plant species composition and community structure (Lal et al. 2010; Kelkar et al. 2013; MolinaHernández \& van Tussenbroek 2014).

Herbivore-induced shifts in community dynamics, structure and species composition have been widely studied for terrestrial ecosystems (Bowes 1993; Anderson \& Briske 1995; Augustine \& McNaughton 1998). Large herbivores may alter plant communities through numerous mechanisms, such as selective grazing which alters competitive interactions among plant species (Anderson \& Briske 1995). The effects of grazing can be particularly strong when herbivores decrease the abundance of one or more dominant plant species that control resource abundance within the community (Olff \& Ritchie 1998). In grasslands for example, ungulates directly influence the nitrogen cycle by adding nitrogen through urine and feces, but more importantly they indirectly affect decomposition processes in soil through changes in plant litter. Resource heterogeneity created by ungulate grazing may alter the competition for resources, 
68 leading to an increase in plant species diversity in grazed areas (Hobbs 1996; McNaughton et al.

69 1997; Bakker et al. 2003; Borer et al. 2014). Interactions of herbivores on plant communities can

70 also be influenced by the effects of abiotic sources of disturbance, such as fire in terrestrial

71 grasslands (Hobbs 1996).

72

73

74

75

76

77

78

79

80

81

82

83

In the Caribbean, climax seagrass communities are dominated by the robust latesuccessional species Thalassia testudinum (slower-growing), which is the preferred food source for green turtles (Bjorndal 1980; Thayer et al 1984; Molina-Hernández \& van Tussenbroek 2014). Green turtles feeding on T. testudinum use a cultivation or rotational feeding strategy (Molina-Hernández \& van Tussenbroek 2014), which is also used by roaming wild ungulates in terrestrial systems (Vavra \& Ganskopp 1998; Bakker et al. 2016). Green turtles create grazing patches within $T$. testudinum meadows which are easily recognized as they graze seagrass leaves in specific areas or patches that they maintain and revisit (Bjorndal 1980; Molina-Hernandez \& van Tussenbroek, 2014). Continuous grazing on T. testudinum increases nitrogen content in the leaves and reduces their lignin content, which improves the quality of the food (Bjorndal 1980; Thayer et al. 1984; Zieman et al. 1984). Rotational grazing by green turtles decreases the aboveground community biomass, particularly that of T. testudinum. Grazed patches are maintained for one to two years after they are abandoned most likely because of reduced leaf growth due to internal carbohydrate depletion; (Fourqurean et al 2010; Lacey et al. 2014;), and the turtles do not return to abandoned patches (Molina-Hernández \& van Tussenbroek 2014). Abandoned patches show thinner and shorter leaves of T. testudinum, with sparser seagrass shoots than ungrazed nearby meadows (Molina-Hernández \& van Tussenbroek 2014). Rotational grazing creates gaps (patches) allowing for colonization of faster-growing seagrass species such as Halodule wrightii and rhizophytic algae (early-successional species). Thus, in these gaps, turtle 
91 herbivory drives community shifts with faster-growing species replacing slower-growing

92 dominant species (Molina-Hernández \& van Tussenbroek 2014, Lacey, et al. 2014). After

93 abandonment, the recovery of grazed patches to pre-grazing conditions may take several years

94 (Molina-Hernández \& van Tussenbroek 2014).

95

Seagrass community structure and dynamics are highly influenced by competition for light (Fourqurean et al. 1995; Ralph et al. 2007) and nutrients (Williams 1987; Williams 1990; Fourqurean et al. 1995; Touchette \& Burkholder 2000; Lee et al. 2007; Leoni et al. 2008). In the shallow seagrass beds in Caribbean reef lagoons, light availability is commonly high (Enríquez \& Pantoja-Reyes 2005) but when T. testudinum is dominant, the canopy itself reduces light availability under de canopy (Williams 1987; Enríquez \& Pantoja-Reyes 2005). However, in grazed patches $T$. testudinum leaves are shorter and abandoned patches have less dense canopy and thinner T. testudinum leaves, and the reduced seagrass canopies in the grazed and abandoned patches are not expected to attenuate light, so competition for light is unlikely in turtle-grazed areas. Instead, nutrient availability in Caribbean seagrass meadows is fundamental in the process of succession described by Williams (1990). Williams (1990) reported that during the first stages of succession, faster-growing seagrass species and rhizophytic algae are the primary successive species to recruit to new areas which stabilize sediments and increase organic matter content, and ammonium concentration in pore water. Slower-growing T. testudinum increases gradually in abundance, and when T. testudinum becomes dominant, ammonium concentration drops again because this climax species withdraws ammonium until levels below the requirements of early-successional species. Plant in the communities influence nutrient availability, but also changes in nutrient supply influence the species composition of the community. For example, when nutrient supply increases (eutrophication), an increase in the 
114 faster-growing seagrass species, such as Halodule wrightii or Syringodium filiforme and

115 rhizophytic macroalgae may occur, eventually replacing T. testudinum (Fourqurean et al. 1995;

116 Davis \& Fourqurean 2001; Ferdie \& Fourqurean 2004).

117 To date, there is little data on the underlying mechanisms associated with community

118 shifts due to turtle grazing. Fourqurean et al. (2010), Ballorain (2010) and Christianen et al.

$119(2011,2014)$ studied changes in seagrass communities when recovering from grazing after

120 placement of turtle exclusion cages; but the recovery trajectory not necessarily is the precise

121 reverse of the trajectory of impact. Thus, following changes in the seagrass meadow when

122 grazing pressure increases may be a better approach to discern the main drivers for the shifts in

123 the seagrass vegetation. In the present study, we monitored changes in patches that were

124 clipped/grazed for different duration (which we consider equivalent to grazing pressure). By

125 comparing different levels of grazing pressure (grazing duration), we aim to answer two

126 questions: i) does rotational grazing change nutrient availability in sediments? and ii) if such

127 changes occur, what are the consequences for the species composition of the vegetation? We

128 hypothesize that early-successional rhizophytic algae and seagrass species (faster-growing) will

129 become more abundant if nutrient availability changes under increasing grazing pressure. 
The study was carried out in Puerto Morelos reef lagoon, on the northeastern coast of the

136 Yucatan Peninsula, Mexican Caribbean. The reef lagoon is delimitated by a fringing reef that

137 extends parallel to the coast from north to south. The lagoon is governed by marine conditions,

138 and is between 550 and 3000 m wide, with a mean depth of 3-4 m (INE 2000; Rodriguez-

139 Martinez et al. 2010). The calcareous sandy bottom is covered with a mixed macrophyte

140 community dominated by Thalassia testudinum, accompanied by Syringodium filiforme,

141 Halodule wrightii and rhizophytic algae (i.e. Halimeda spp. Penicillus spp., Rhipocephalus spp.,

142 Udotea spp.; van Tussenbroek 2011). While most of the extensive seagrass bed is not grazed by

143 turtles, specific locations are frequently visited by them. In these locations, turtles create a

144 mosaic of grazed (grazed continuously), ungrazed and recently abandoned patches (Molina

145 Hernández \& van Tussenbroek 2014). The site of this study was such an area located $650 \mathrm{~m}$ from 146 the coast $\left(20^{\circ} 51^{\prime} 44.1^{\prime \prime} \mathrm{N}, 86^{\circ} 51^{\prime} 46^{\prime \prime} \mathrm{W}\right)$, at a depth of 3-4 m.

147 Simulated turtle grazing

We established four levels of grazing pressure (based on grazing duration): Control as a reference condition, Short-term, Medium-term and Long-term grazing, and one level of Recovery (Table 1) with five replicates (patches) for each level. The experimental patches were created in two different previous conditions: ungrazed or previously grazed by green turtles.

152 Control patches were established in ungrazed sections of the seagrass bed without clipping. Short-term and Medium-term experimental patches were created also in the ungrazed seagrass

154 bed. We simulated turtle grazing by "clipping" leaves of seagrasses (T. testudinum and $S$. filiforme) and thalli of rhizophytic algae $\sim 3 \mathrm{~cm}$ above sediment level with scissors (which is the average size of shoot leaves after being grazed by green turtles), removing the clipped portions

157 of the seagrasses and algae to mimic ingestion by turtles. Although $S$. filiforme and calcareous 
158 green algae are not preferred food for the turtles, they do crop them incidentally. In addition, our 159 objective was to show how grazing of all species, without preference, can still lead to changes in 160 competitive hierarchy and therefore species composition. In this way we mimicked turtle patches 161 with irregular shape and 6-12 $\mathrm{m}^{2}$ in size, which is the minimal patch size registered by Molina-

162 Hernández \& van Tussenbroek (2014) in the same reef lagoon. Distances between adjacent

163 patches were $\geq 1.5 \mathrm{~m}$, which corresponded with the median distance of naturally created grazing 164 patches by turtles in the study site. Seagrasses were re-clipped at $\sim 15 \mathrm{~d}$ intervals which coincide 165 with the time needed for $T$. testudinum blades to regrow $\geq 5 \mathrm{~cm}$ above the blade/sheath junction 166 (Molina-Hernández \& van Tussenbroek 2014). The Short- and Medium-term patches were 167 clipped for 4 and 8 months, respectively. The Long-term grazing areas were created in 168 previously grazed patches that had been abandoned by turtles, which were easily identified, 169 presenting sparse vegetation of T. testudinum with thinner and shorter leaves than the 170 surrounding ungrazed seagrass bed (Molina-Hernandez \& van Tussenbroek 2014); the leaves in 171 these patches did not have evidence of turtle bites which are clearly visible when present. Within 172 the previously grazed patches, experimental quadrats of $1 \mathrm{~m}^{2}$ were established and seagrasses 173 and algae were clipped as described above for 8 months. The Long-term treatment represents a 174 seagrass scenario under heavy grazing pressure. The remaining areas in the same patches were 175 assigned for the Recovery level without clipping. At 4 occasions in different patches (out of 18 176 times that clipping was applied), the turtles visited our experimentally clipped patches, which it 177 was evident by short-cropped leaves; manual clipping was ceased when this occurred.

Sediment and pore-water analysis Sediment samples were collected to determine organic matter content at the end of our grazing treatments in February 2016. Three samples were taken randomly at each patch using 5 
$181 \mathrm{~cm}$ diameter tubes at a depth of $10 \mathrm{~cm}$. The samples were pooled per patch, homogenized after 182 removing plant material, and dried at $60^{\circ} \mathrm{C}(\sim 48 \mathrm{~h})$ to be weighed afterwards. Subsamples of 20

183 dry g were used to determine organic matter content through loss of dry weight after dissolution 184 in hydrochloric acid (12.5\%), which dissolves the carbonate sediments. The remaining sediment 185 samples were used to granulometric analysis (Particle Analyzer CAMSIZER, Institute of 186 Engineering, UNAM). Pore-water samples were taken anaerobically at each patch at four different times starting one month after cessation of clipping, on 3 March, 5, 11 April and 6 May 2016. A rhizon pore water sampler (0.2 $\mu \mathrm{m}$ pore size, $5 \mathrm{~cm}$ depth; Eijkelkamp Agri-Search Equipment, Giesbeck, the Netherlands) connected to a $50 \mathrm{~mL}$ syringe was introduced in the sediment, and for 90-120 minutes allowing the syringe to slowly fill with porewater. In the laboratory, sulfide concentrations were measured in $4 \mathrm{ml}$ of each sample within 4 hours of collection. Sulfide concentrations were measured in a mixture of 50\% sample and 50\% Sulfide Anti-Oxidation Buffer (SAOB) (Lamers et al. 1998) with a HI 4115 Silver/Sulphide combination electrode (Hanna Instruments, Woonsocket RI USA), and a WTW multimeter (multi 340i/SET). The remaining pore-water of the samples was frozen $\left(-20^{\circ} \mathrm{C}\right)$ until further analysis. Concentrations of phosphate $\left(\mathrm{PO}_{4}{ }^{3-}\right)$, nitrate $\left(\mathrm{NO}_{3}{ }^{-}\right)$and ammonium $\left(\mathrm{NH}_{4}{ }^{+}\right)$were measured on an Analytical order 1000640-1 3 System AutoAnalyser (Bran\&Lubbe, 2 Seal Model II systems; continuous analysis

Norderstedt, Germany) with ammonium molybdate, hydrazine sulfate and salicylate, respectively. Detection limits for the analysis was $1 \mu \mathrm{M}$ for sulfide concentrations, $0.2 \mu \mathrm{M}$, for ammonium concentrations, and $0.1 \mu \mathrm{M}$ for nitrate and phosphate concentrations. 
204 Ganadería, Desarrollo Rural, Pesca y Alimentación, México. At the end of the experiment

205 (February-March 2016), foliar shoots of seagrasses and thalli of rhizophytic algae were counted

206 for each species in a randomly placed PVC ring (diameter $=30 \mathrm{~cm}$ area $\left.=0.07 \mathrm{~m}^{2}\right)$. In each

207 patch, two core samples (diameter $=11.2 \mathrm{~cm}, \mathrm{~h}=\sim 40 \mathrm{~cm}$ ) were taken after 25 days of the last

208 clipping, allowing for regrowth of leaves and thalli before harvesting. In patches with low

209 density of T. testudinum, additional foliar shoots of T. testudinum were collected randomly by

210 cutting the vertical rhizome below the substratum to complete 15 shoots for morphometric

211 measurements. One of the core samples was processed for T. testudinum and the other for the

212 early-successional plants (rhizophytic algae and S. filiforme).

In the laboratory, plant samples were stored in a refrigerator and processed within 15 separated into below-ground roots, horizontal rhizome, vertical rhizome, sheaths, and aboveground leaf sections. The leaves were cleaned of epiphytes with a razor blade. Complete thalli of rhizophytic algae were also selected from core samples. Thalli were rinsed but attached sand grains to the rhizoids were not removed. Epiphytes were also removed with a razor blade. The plant fractions and thalli of rhizophytic algae were placed in a drying oven for at least 36 hours at $60^{\circ} \mathrm{C}$ until completely dry, after which their dry weight was determined on an analytical balance.

Dried horizontal rhizomes and leaves for T. testudinum were preserved for further analysis. core sample was measured with a ruler. 
225 Nutrients and soluble carbohydrates analyses in late-successional seagrass species T.

226 testudinum

Tissue nitrogen $(\mathrm{N})$ and carbon $(\mathrm{C})$ were measured from $3 \mathrm{mg}$ dried and ground leaves of

T. testudinum with a carbon-nitrogen-sulphur analyser (type NA1500, Carlo Erba Thermo Fisher

229 Scientific, USA), coupled via an interface (Finnigan Conflo III) to a mass spectrometer (Thermo

230 Finnigan Delta Plus, USA). Total concentration of phosphorous (P) in T. testudinum leaves, was

231 measured with inductively-coupled- plasma emission spectrometry (IRIS Intrepid II, Thermo

232 Electron Corporation, Franklin, MA, USA), after digestion with nitric acid, following Smolders

233 et al. (2006). Total soluble carbohydrates were measured in T. testudinum horizontal rhizomes.

234 The sugars were extracted from ground rhizomes in ethanol at $80^{\circ} \mathrm{C}$. Extracts were then

evaporated until dry at room temperature, under a stream of compressed air and subsequently re-

236 dissolved in $\mathrm{dH}_{2} \mathrm{O}$. Samples were analyzed with a spectrophotometer using a hydrochloric

$237 \mathrm{acid} /$ resorcinol assay standardized to sucrose (Huber \& Israel 1982).

238

239

240

241

242

243

244

245

246

\section{Statistical analysis}

A one-way ANOVA was applied to analyze the effects of the different levels of grazing pressure on the percentage of organic matter content in sediments, and in the percentage of fine sediments (0.3-0.189 mm of grain size). Nested ANOVA analyses were used to test grazing effect on phosphate $\left(\mathrm{PO}_{4}{ }^{3-}\right)$, nitrate $\left(\mathrm{NO}_{3}{ }^{-}\right)$and ammonium $\left(\mathrm{NH}_{4}{ }^{+}\right)$concentrations in pore-water samples, with pore-water samples per patch were nested within grazing level. Differences among levels were determined with a post-hoc Tukey HSD tests. To test for grazing effects on seagrass community, a two-way ANOVA was applied to the total biomass and density per species group per patch, with grazing pressure and species (group) as fixed factors. S. filiforme and rhizophytic

PeerJ reviewing PDF | (2019:03:35652:1:1:NEW 9 Jul 2019) 
247 algae were considered together as early-successional plants and T. testudinum as the late-

248 successional species. Using a one-way ANOVA analysis, we also tested the relative contribution

249 of early-successional species to the total density of the vegetation $((S$. filiforme + rhizophytic

250 algae $) /($ S. filiforme + rhizophytic algae $+T$. testudinum $))$. To test for grazing effects on $T$.

251 testudinum, a one-way ANOVA was applied to the percentage of nitrogen, carbon, and

252 phosphorous concentration in leaves, and for the soluble carbohydrates in rhizomes ( $\mu$ mol g DW

$253^{-1}$ ). Differences among levels were determined with a post-hoc Tukey HSD tests. Density data

254 were $\log$ transformed prior to analysis $(\log +1)$, and percentages were arcsine transformed prior to

255 analysis. All analyses were conducted using Systat 11 software. Assumptions of normality and

256 homoscedasticity were tested through graphical analysis of the residuals. For the two-way

257 ANOVA analysis, two outliers in T. testudinum total biomass data and one for early-successional

258 species were removed after residual analysis. In the same way, four outliers in density data of the

259 early-successional species were removed. For the one-way ANOVA analysis of the relative

260 contribution of early-successional species to density, one outlier was removed. To test the

261 relationship of total biomass of $T$. testudinum and pore-water ammonium concentrations, a linear

262 regression was performed using sub-replicates of ammonium measurements within each patch

263 and the total biomass of this species in each patch. Five outliers were removed.

\section{RESULTS}

Simulated turtle grazing

We simulated green turtle rotational grazing as closely as possible at appropriate temporal and spatial scales. Re-clipping intervals mimicked natural turtle grazing rates and size 
269 of the experimental patches corresponded with the minimal size created by green turtles in the

270 area. The fact that turtles grazed on 4 separate occasions in our clipped patches (which were

271 different Medium-term patches) could be indicative that the manual manipulation to copy the

272 grazing behavior by turtles was sufficiently realistic. Visits to our experimental patches were

273 frequent and therefore we could always establish that turtles had visited the site; their grazing

274 and our clipping were applied with almost the same frequency, thus creating a minimal bias.

Sediment and pore-water analyses in grazing levels

Sediment analysis showed no differences in organic matter content among grazing levels

for the Long-term and Recovery levels $\left[\mathrm{F}_{(4,20)}=11.2993 \mathrm{p}<0.01\right.$; Table 2]. Ammonium

concentrations in sediment pore-water were significant different among levels $\left[\mathrm{F}_{(4,20)}=3.398 \mathrm{p}<\right.$

0.05; Table 3] Ammonium concentrations $\left(\mathrm{NH}_{4}{ }^{+}\right)$were lowest for the Controls (mean $\pm \mathrm{SE}=4.6$

$\pm 1.5 \mu \mathrm{M}$ ), and highest for the Medium- and Long-term levels (mean $\pm \mathrm{SE}=9.2 \pm 0.8 \mu \mathrm{M}$ and

$11.0 \pm 2.2 \mu \mathrm{M}$, respectively; Fig. 1). Pore-water nitrate $\left(\mathrm{NO}_{3}{ }^{-}\right)$and phosphate $\left(\mathrm{PO}_{4}{ }^{3-}\right)$

concentrations were almost below detection level and no differences among levels were found detection limit $(1 \mu \mathrm{M})$ and a highest concentration of $382.5 \mu \mathrm{M}$; no statistical analyses were applied to these data. 
total biomass of Thalassia testudinum decreased as the grazing pressure increased; it was highest

292 for the Controls (mean $\left.\pm \mathrm{SE}=1161.5 \pm 73.6 \mathrm{gr} \mathrm{DW} \mathrm{m}^{-2}\right)$, and lowest in the Long-term patches

$293\left(\right.$ mean $\left.\pm \mathrm{SE}=220.1 \pm 73.4 \mathrm{gr} \mathrm{DWm}^{-2}\right)$. T. testudinum biomass was slightly higher after 8 months

294 of recovery from grazing but still lower when compared with Control level (Fig. 2). Trends with

295 grazing pressure in the total biomass of the early-successional species (Syringodium filiforme and

296 rhizophytic algae) differed from those registered for the late-successional species, T. testudinum.

297 Total biomass of the early-successional plants was higher for the Medium- and Long-term levels

298 (mean $\pm \mathrm{SE}=40.1 \pm 9.5 \mathrm{gr} \mathrm{DW} \mathrm{m}^{-2}$ and $51.3 \pm 25.4 \mathrm{gr} \mathrm{DW} \mathrm{m}^{-2}$, respectively) than for the Short-

299 term level $\left(\right.$ mean $\left.\pm \mathrm{SE}=34.6 \pm 13.6 \mathrm{gr} \mathrm{DW} \mathrm{m}^{-2}\right)$, which had a decline in biomass of early-

300 successional species in comparison with the Controls (mean $\pm \mathrm{SE}=107.0 \pm 24.5 \mathrm{gr} \mathrm{DW} \mathrm{m}^{-2}$ ).

301 Recovery level had similar values as the Short-term level (mean $\pm \mathrm{SE}=34.3 \pm 27.1 \mathrm{gr} \mathrm{DW} \mathrm{m}^{-2}$ )

302 (Fig.2). Trends in density were like those of biomass (Supplementary material Table A). The

303 two-way ANOVA analysis, testing for differences in total biomass per species group (early- and

304 late-successional) and grazing levels resulted in a significant interaction between species group

305 and levels $\left[\mathrm{F}_{(4,37)}=21.2575 \mathrm{p}<0.01\right]$ confirming that the trends of changes in biomass differed

306 between the late- and early-successional species for the grazing levels. The two-way ANOVA

307 for density showed the same results $\left[\mathrm{F}_{(4,36)}=8.356 \mathrm{p}<0.01\right]$. When we considered the relative

308 contribution of early-successional species to the total density of vegetation we found that the

309 contribution of $S$. filiforme and rhizophytic algae to the total density was significantly higher in

310 the Long-term patches in comparison with the other grazing levels (one-way ANOVA $\left[\mathrm{F}_{(4,19)}=\right.$

$3118.2385 \mathrm{p}<0.01]$ Fig. 3, Supplementary material Table B). The linear regression to test the

312 relationship between ammonium availability and T. testudinum total biomass showed a 
313 significant inverse relationship $\left[\mathrm{r}^{2}=0.753 \mathrm{p}<0.001 \mathrm{n}=20\right]$. Ammonium concentrations in

314 sediment increased in relation with a decrease in T. testudinum total biomass (Fig. 4).

315 Seagrass nutrient and carbohydrate content

316 Simulated grazing resulted in an increase of nitrogen (N\%) in T. testudinum leaves. All

317 grazing levels, including the Long-term level showed significant higher $\mathrm{N}$ concentrations when

318 compared with control level $\left[\mathrm{F}_{(4,17)}=77.020, \mathrm{p}<0.01\right]$. The $\mathrm{N}$ concentrations in the recovery

319 level also was significant higher compared to control level. In contrast, Carbon (C\%) did not

320 show significant differences among levels $\left[\mathrm{F}_{(4,19)}=1.180, \mathrm{p}=0.35\right]$. Consequently, the control

321 and recovery level showed significant higher tissue $\mathrm{C}: \mathrm{N}$ in $T$. testudinum when compared to the

322 grazed levels $([\mathrm{F}(4,19)=5.511 \mathrm{p}<0.01]$ in $\mathrm{C}: \mathrm{N}$ ratio $)$. Contrary, N:P ratio did not show

323 significant differences among grazing levels $\left(\left[\mathrm{F}_{(4,19)}=1.059 \mathrm{p}=0.40\right]\right)$. Soluble carbohydrates

324 content in T. testudinum horizontal rhizome had significant differences among all levels $\left[\mathrm{F}_{(4,19)}=\right.$

325 5.511, $\mathrm{p}<0.01]$; it decreased at higher grazing pressure with a drastic decline in Long-term

326 patches (Table 4).

327

328

\section{DISCUSSION}

Large herbivores such as green turtles may be important agents of change in ecosystems.

Rotational grazing by turtles has negative effects on the above-ground community biomass and 
334 enhances nutrient availability, which in turn drives the shift in the species composition of the

335 vegetation (Fig. 5).

336 Changes in Thalassia testudinum under a rotational grazing regime

337 Simulated turtle grazing increased food quality, as nitrogen $(\mathrm{N})$ content in T. testudinum

338 leaves increased, which was also reported by Bjorndal (1980), Moran \& Bjorndal (2007), and

339 Molina-Hernández \& van Tussenbroek (2014). Phosphorus (P) content instead did not change

340 among grazing levels. Holzer \& McGlathery (2016) studied responses of T. testudinum to

341 grazing in a phosphorus limited environment in Bermuda in plots with and without artificial

342 fertilizers; and found that the cultivation grazing response of the turtles depended on the

343 availability of phosphorus. In carbonate sediments phosphorus $(\mathrm{P})$ is often the growth-limiting

344 nutrient of many tropical seagrasses (Fourqurean et al. 1995). For seagrasses, tissue N:P ratio

345 reflects the relative availability of these elements in the environment. In T. testudinum leaves, a

$346 \mathrm{~N}: \mathrm{P}$ ratio around 30:1 is present when there is a critical level and balance in the availability of

347 both nutrients (Fourqurean \& Zieman 2002). As the N:P ratios of this study were never higher

348 than 21 , we can assume that $\mathrm{P}$ was not limiting in our experiments. Molina-Hernández \& van

349 Tussenbroek (2014) found much higher N:P ratios $(>34)$ in turtle-grazed areas within the same

350 reef lagoon in 2011. Differences between the two study areas in terms of P availability within

351 the lagoon maybe due to differences in location or may be attributed to the massive influx of

352 Sargassum spp. in 2015, during which enormous amounts of organic matter and nutrients were

353 imported, resulting in higher $\mathrm{P}$ availability, and therefore higher $\mathrm{P}$ concentrations in seagrass

354 tissues throughout the lagoon (Van Tussenbroek et al. 2017). Thus, $\mathrm{N}$ and not $\mathrm{P}$ was limiting to

355 T. testudinum (and likely the other seagrasses), during our study. 
The leaf $\mathrm{N}$ content was similar at all levels of grazing. The Long-term patches were

357 previously grazed patches abandoned by the turtles. Thus, depletion of nutrient $(\mathrm{N})$ content in

358 leaves was not the reason for turtles to abandon the patches. The paradigm about $\mathrm{N}$ depletion in

359 tissues as a patch abandonment cue is not supported by our data nor to those reported in previous

360 studies (Moran \& Bjorndal 2007; Fourqurean et al. 2010). Turtles most likely stopped grazing

361 because not much new tissue was formed, as shoot density decreased (this study) or the leaves

362 stopped growing as suggested by Lacey, et al. (2014), which was likely driven by the decline in

363 soluble carbohydrates content (table 4, Moran \& Bjorndal 2007). Robust seagrass species like $T$.

364 testudinum have a large proportion of tissue in non-photosynthetic plant parts such as roots and

365 rhizomes that are maintained by photosynthesis in the leaves, which are reduced due to grazing

366 (Williams 1988; Molina-Hernández \& van Tussenbroek 2014; Bakker et al. 2016). At first, the

367 carbohydrate reserves in the rhizomes are used to maintain the metabolism of below-ground

368 structure, but when these are depleted, below-ground tissues are lost resulting in a decrease in

369 shoot density. Other indicators of the stress of grazing on seagrasses are reduced leaf length

370 (direct effect of grazing) and width (most likely due to metabolic stress) as reported by Moran \&

371 Bjorndal (2005), Fourqurean et al. (2010), and Molina-Hernández \& van Tussenbroek (2014).

372 The widths of the leaves increased slightly in the Recovery level, but after 8 months of recovery

373 the leaves were still narrower than those of the Control level. These data emphasize the

374 detrimental effect of prolonged turtle grazing on the shoots of T. testudinum.

Does rotational grazing change nutrient availability in sediments?

377 down (grazing) and bottom-up effects (nutrients; De Mazancourt et al. 1998; Holzer \&

378 McGlathery 2016). Ammonium concentrations in pore-water sediments showed the inverse 
379 tendency to T. testudinum density and biomass; which decreased when grazing pressure

380 increased. T. testudinum is a late-successional species that as succession progresses outcompetes

381 early-successional species by withdrawing nutrients below the earlier seral species requirement

382 levels (Williams, 1990). The decrease in T. testudinum biomass induced by grazing pressure

383 increased ammonium availability in pore-water, likely because less ammonium was utilized by

384 T. testudinum. This was supported by the inverse relationship between pore-water ammonium

385 concentrations and T. testudinum total biomass.

In terrestrial systems, nutrient input from urine and feces may also alter nutrient cycling

387

388

389

390

391

392

393

394

395

396

397

398

399

400

(Hobbs 1996; Bakker et al. 2003). However, in marine systems green turtles often defecate at their resting areas when they become active (Bjorndal 1980), and turtle feces floats, so urine and feces may not make a substantial contribution to changes in ammonium availability within sediment of grazed patches (Thayer et al. 1984; Moran \& Bjorndal 2005; Moran \& Bjorndal 2007). Changes of organic matter in sediments are also expected to influence nutrient availability. We expected that simulated grazing, especially in Long-term grazed patches, would result in decreased organic content of sediments, as turtles removed leaf material, and the shortcut grazed leaves were less likely to attenuate waves which increases trapped organic matter (Thayer et al. 1984; Moran \& Bjorndal 2005; Christianen et al. 2011). However, we did not find differences in organic sediment content among the grazing levels, even though the capacity to trap fine particles was reduced in grazed levels, as indicated by the lower proportion of fine sediments in the Long-term grazed and Recovery patches. Most likely, dying below-ground tissues build-up at increased grazing levels, contributing to organic matter in the sediments. Also, Moran \& Bjorndal (2007) found no changes in organic matter content in sediments after 16 
401 months of simulated turtle grazing, with the effects of grazing on sediments possibly being site

402 and species-dependent.

403

404 Can changes in the macrophyte community composition by selective turtle grazing be associated 405 with nutrient availability?

Rotational grazing reduced the total biomass of the macrophyte community, but the

407

408

409

410

411

412

413

414

415

416

417

418

419

420

421

422 trends of change differed for early- and late-successional species, resulting in a shift in

community towards faster-growing early-successional species, also reported by Molina-

Hernández \& van Tussenbroek (2014). While T. testudinum decreased with prolonging grazing pressure, early-successional species decreased in abundance at Short-term grazing pressure, remained stable during Medium-term grazing, but increased when grazing was Long-term. $S$. filiforme is an early-successional species crop occasionally and incidentally by green turtles. Our Short-term grazing level showed a decrease in S. filiforme biomass, probably due to its thinner rhizomes and less carbohydrate reserves to compensate the losses of photosynthetic tissue (Molina-Hernández \& van Tussenbroek 2014), but they can also occupy open spaces and utilize available resources faster than $T$. testudinum because they have higher rhizome elongation rates (Williams 1987, Marba \& Duarte 1998). Grazing has been shown to disrupt competitive hierarchies (Anderson \& Briske 1995), by compromising a species ability to cope with its competitors or by facilitating growth potentials of otherwise subdominant plant species. Changes in seagrass dominance in relation with mega herbivore grazing in tropical seagrasses have been reported before (Lal et al. 2010; Liebvre et al. 2017). Liebvre et al. 2017 reported that exclusion cages established in a manatee grazing area led a mixed seagrass community of $S$. filiforme and

PeerJ reviewing PDF | (2019:03:35652:1:1:NEW 9 Jul 2019) 
$423 H$. wrightii (both important in manatee diets) to shift to a dominant $S$. filiforme seagrass bed.

424 They suggested higher rates of production, lateral branching and space occupation improved the

425 competitive superiority of $S$. filiforme over that of $H$. wrightii for acquisition of nutrients,

426 occupation of space, and anchorage in sediments. Our study showed that when T. testudinum

427 declined at higher grazing pressure, ammonia concentrations in sediments increased. Therefore,

428 this nutrient increase likely contributed to the competitive balance in favor to $S$. filiforme and

429 rhizophytic algae. This process is reversed during recovery (Fig. 5).

430

431

432

433

434

435

436

437

438

439

440

441

442

443

444
Implications

Large herbivores like green turtles can have significant impacts as ecosystem engineers. 2005; Molina-Hernández \& van Tussenbroek 2014). However, on a landscape-scale, it increases species and structural diversity (Molina Hernández \& van Tussenbroek 2014), by creating gaps allowing for the colonization of early-successional species like S. filiforme, $H$. wrightii and rhizophytic algae. Changes in morphology and species richness of seagrasses have been related with changes in the abundance and diversity of their associated fauna (Ray et al. 2014); and whether this applies to meadows under a rotational-grazing regime merits further investigation.

When turtles reach a density beyond the carrying capacity for turtle grass recovery (represented by our Long-term grazing level), they drive species replacement of a whole seagrass bed towards a higher dominance of faster-growing and early successional seagrass (MolinaHernández \& van Tussenbroek 2014), inducing a pattern shift through meadows in lower successional stages (Kelkar et al. 2013) or cause complete loss of the meadow (Fourqurean et al. 2010). Herbivorous sea turtles may act as switches controlling transitions between alternative 
445 ecosystem states as they can affect the susceptibility of the ecosystem to abiotic disturbances,

446 like ungulates in terrestrial systems. Ungulates may provide a switch between a fire-prone or a

447 fire-resistant ecosystem, which also depends on environmental factors controlling primary

448 productivity (Hobbs 1996). Turtle grazing is also increasing as a consequence of successful

449 conservation of green turtles and the absence of top predators like sharks (Fourqurean et al.

450 2010; Christianen et al. 2014; Heithaus et al. 2014; Molina-Hernández \& van Tussenbroek

451 2014). These trends could significantly impact seagrass meadows, and consequences of

452 reduction or loss of T. testudinum maybe synergistic with other disturbances (van Tussenbroek et 453 al. 2014). For example, T. testudinum is a deeply rooted species with a well-developed below-

454 ground rhizome-root system and resists hurricanes better than faster-growing seagrass species

455 with less below-ground biomass (Cruz-Palacios \& van Tussenbroek 2005). Reduction of $T$.

456 testudinum by grazing may thus enhance the vulnerability of the total seagrass bed to hurricanes.

457 Our study shows that turtle grazing influences nutrient cycling, likely by reducing the

458 abundance of the dominant competitor for nutrients in the sediments, thereby allowing for an

459 increase in abundance of faster-growing species that take advantage of the newly available

460 resources (Fig. 5). Eutrophication, now widespread in the Caribbean, has similar consequences

461 for seagrass plant communities (van Tussenbroek et al. 2014). Turtle grazing herbivory may

462 potentially threaten stability of meadows throughout the Caribbean; especially in synergy with

463 other human-induced or natural stressors like eutrophication and hurricanes. Christianen et al.

464 (2018) provided evidence of green turtle grazing as a main factor contributing to invasion of the

465 non-native seagrass species Halophila stipulacea in the Caribbean. 


\section{CONCLUSIONS}

Rotational grazing by turtles has negative effects on the above-ground community biomass and causes changes in species composition of the vegetation. Our study showed that

471 when Thalassia testudinum biomass declined at higher grazing pressure, ammonium

472 concentrations in the pore-water sediment increased, suggesting that the continuous removal of

473 above-ground biomass of the dominant $T$. testudinum enhances nutrient availability in sediment.

474 We found that even simulated grazing of all species (Syringodium filiforme and rhizophytic 475 algae) without preference, can still lead to changes in competitive hierarchy and therefore species 476 composition. Therefore, green turtles may be important agents of change in ecosystems. When

477 turtles reach a density beyond the carrying capacity for turtle grass recovery, they may drive 478 species replacement of a whole seagrass bed inducing a pattern shift through meadows in lower 479 successional stages or may cause the complete loss of a meadow. In this way, herbivorous sea turtles act as switches controlling transitions between alternative ecosystem states as they can affect the susceptibility of the ecosystem to abiotic disturbances, like ungulates in terrestrial systems. To establish better conservation strategies, it is necessary to continue studying the interactions between turtle grazing and seagrasses, including the implications of seagrass community shifts due to turtle grazing to the stability and maintenance of ecosystem services of the seagrass meadows. 
489

490

491

492

493

494

495

496

497

498

499

500

501

502

503

504

505

506

507

508

509

510

511

512

\section{AKNOWLEDGEMENTS}

Guadalupe Barba Santos, Hazel M. Canizales Flores, Luuk Leemans, Nancy E. Burgos Veneroso supported this study in the field. The Academic Service of Meteorological and Oceanographic Monitoring (SAMMO) provided meteorological data. Useful comments and input during development of this manuscript from Darren Brown are acknowledged. The first author acknowledges The Mexican Consejo Nacional de Ciencia y Tecnología (CONACyT) for providing $\mathrm{PhD}$ fellowship support.

\section{REFERENCES}

Anderson Val. J. \& D. D. Briske. 1995. Herbivore-induced species replacement in grasslands: Is it driven by herbivory tolerance or avoidance? Ecological Applications. 5 (4): 1014-1024.

Augustine D. J. \& S. J. McNaughton. 1998. Ungulate effects on the functional species composition of plant communities: herbivore selectivity and plant tolerance. Journal of Wildlife Management. 62 (4): 1165-1183.

Bakker, C., J. M. Blair \& A. K. Knapp. 2003. Does resource availability, resource heterogeneity or species turnover mediate changes in plant species richness in grazed grasslands? Oecologia. 137: 385-391.

Bakker, E. S., J. F. Pagès R. Arthur \& T. Alcoverro. 2016. Assessing the role of large herbivores in the structuring and functioning of freshwater and marine angiosperm ecosystems. Ecography: 39:162-179.

Ballorain, K. 2010. Ecologie trophique de la tortue verte Chelonia mydas dans les herbiers marins et algueraies du sud-ouest de l'océan Indien. Ph Thesis. Universite de la Reunion. 286 pp. 
513 Bjorndal, K. A. 1980. Nutrition and grazing behavior of the green turtle Chelonia mydas. Marine $514 \quad$ Biology. 56: 147-154.

515 Borer, E., E. W. Seabloom, D. S. Gruner, W. S. Harpole, H. Hillebrand, E- M. Lind, P. B. Adler, 516 J. Alberti, T. M. Anderson, J. D. Bakker, L. Biederman, D. Blumenthal, C. S. Brown, L. 517 A. Brudvig, Y. M. Buckley, M. Cadotte, C. Chu, E. E. Cleland, M. J. Crawley, P. Daleo, 518

Christianen, M. J., L. L. Govers, T. J. Bouma, W. Kiswara, J. G. M. Roelofs, L. P. M. Lamers \& M. M. van Katwijk. 2011. Marine megaherbivore grazing may increase seagrass tolerance to high nutrient loads. Journal of Ecology. 100(2): 546-560.

Christianen, M. J., P. M. J. Herman, T. J. Bouma, L. P. M. Lamers, M. M. van Katwijk, T. van der Heide, P. J. Mumby, B. R. Silliman, S. L. Engelhard, M. van der Kerk, W. Kiswara \& J. van de Koppel. 2014. Habitat collapse due to overgrazing threatens turtle conservation in marine protected areas. Proceedings of the Royal Society B. 281: 20132890. 
534 Christianen M. J., F. O. H. Smulders, M. S. Engel, M. I. Nava, S. Willis, A. O. Debrot, P. J.

535 PalsbØ11, J. A. Vonk \& L. E. Becking. 2018. Megaherbivores may impact expansion of 536 invasive seagrass in the Caribbean. Journal of Ecology. 1-13.

537 Cruz-Palacios V. \& B. I. van Tussenbroek. 2005. Simulation of hurricane-like disturbances on a 538 Caribbean seagrass bed. Journal of Experimental Marine Biology and Ecology. 324: 44$539 \quad 60$.

540 Davis, B. C. \& J. W. Fourqurean. 2001. Competition between the tropical alga, Halimeda 541 incrassata, and the seagrass, Thalassia testudinum. Aquatic Botany. 71: 217-232.

542 De Mazancourt, C., M. Loreau \& L. Abbadie. 1998. Grazing optimization and nutrient cycling: when do herbivores enhance plant production? Ecology. 79: 2242-2252.

544 Enríquez, S. \& N. I. Pantoja-Reyes. 2005. Form-function analysis of the effect of canopy 545 morphology on leaf self-shading in the seagrass Thalassia testudinum. Oecologia. 145: $235-243$.

547 Ferdie, M. \& J. W. Fourqurean. 2004. Responses of seagrass communities to fertilization along a gradient of relative availability of nitrogen and phosphorus in a carbonate environment. Limnology and Oceanography. 49 (6): 2082-2094.

Fourqurean, J. W., G. V. N. Powell, W. J. Kenworthy \& J. C. Zieman. 1995. The effects of longterm manipulation of nutrient supply on competition between the seagrasses Thalassia testudinum and Halodule wrightii in Florida Bay. Oikos. 72: 349-358.

553 Fourqurean, J. W., J. Zieman. 2002. Nutrient content of the seagrass Thalassia testudinum 554 reveals regional patterns of relative availability of nitrogen and phosphorus in the Florida 555 Keys USA. Biogeochemistry. 61: 229-245. 
556 Fourqurean, J. W., S. Manuel, K. A. Coates. W. J. Kenworthy \& S. R. Smith. 2010. Effects of

557 excluding sea turtle herbivores from seagrass bed: Overgrazing may have led to loss of 558 seagrass meadows in Bermuda. Marine Ecology Progress Series. 419: 223-232.

559 Heithaus, M. R., Alcoverro, T., Arthur, R., Burkholder, D. A., Coates, K. A., Christianen, M. J. 560 A., Kelkar, N., Manuel, S. A., Wirsing, A. J., Kenworthy, W. J. \& Fourqurean, J. W..

561 2014. Seagrasses in the age of sea turtle conservation and shark overfishing. Frontiers in $562 \quad$ Marine Science. 1 (28): 1-6.

563

564

565

566

567

568

569

570

571

572

573

574

575

576

577

Hobbs, T. 1996. Modification of ecosystems by ungulates. The Journal of Wildlife Management. 60 (4): 695-713.

Holzer, K. K. \& K. J. McGlathery. 2016. Cultivation grazing response in seagrass may depend on phosphorus availability. Marine Biology. 163: 88.

Huber, S. C. \& D. W. Israel. 1982. Biochemical basis for partitioning of photosynthetically fixed carbon between starch and sucrose in soybean (Glycine max Merr.) leaves. Plant Physiology. 69: 691-696.

Hughes, A. R., K. J. Bando, L. F. Rodriguez \& S. L. Williams. 2004. Relative effects of grazers and nutrients on seagrasses: a meta-analysis approach. Marine Ecology Series. 282: 8799.

Instituto Nacional de Ecología INE. 2000. Programa de manejo Parque Nacional Arrecife de Puerto Morelos. México. Dirección Ejecutiva de Participación Social, Enlace y Comunicación. 244 pp.

Jackson, J. B. C. 1997. Reefs since Columbus. Coral Reefs. 16 Suppl: S23-S32.

Jackson, J. B. C. 2001. What was natural in the coastal oceans? 98 (10): 5411-5418. 
578 Kaladharan, P., K. P. Saidkoya, V. A. Kunhikoya \& A. Anasukoya. 2013. Turtle herbivory of

579

580

581

582

583

584

585

586

587

588

589

590

591

592

593

594

595

596

597

598 seagrass ecosystems in the Lakshadweep atolls: concerns and need for conservation measures. Journal of the Marine Biological Association of India. 55 (1): 25-29.

Kelkar, N., R. Arthur, N. Marbà \& T. Alcoverro. 2013. Greener pastures? High-density feeding aggregations of green turtles precipitate species shifts in seagrass meadows. Journal of Ecology. 101: 1158-1168.

Lacey, E. A., L. Collado-Vides \& J. W. Fourqurean. 2014. Morphological and physiological responses of seagrasses (Alismatales) to grazers (Testudines: Cheloniidae) and the role of these responses as grazing patch abandonment cues. Revista Biología Tropical. 62 (4): 1535-1548.

Lal, A., R. Arthur, N. Marbà, A. W. T. Lill \& T. Alcoverro. 2010. Implications of conserving an ecosystem modifier: Increasing green turtle (Chelonia mydas) densities substantially alters seagrass meadows. Biological Conservation. 143: 2730-2738.

Lamers L. P., M., H. B. M. Tomassen \& J. G. M. Roelofs. 1998. Sulfate-induced eutrophication and phytotoxicity in freshwater wetlands. Environmental Science and Technology. 32: 199-205.

Lee, K., S. R. Park \& Y. K. Kim. 2007. Effects of irradiance, temperature, and nutrients on growth dynamics of seagrasses: A review. Journal of Experimental Marine Biology and Ecology. 350: 144-175.

Leiebvre, L. W., J. A. Provancha, D. H. Slone \& W. J. Kenworthy. 2017. Manatee grazing impacts on a mixed species seagrass bed. Marine Ecology Progress Series. 564:29-45 
599 Leoni, V., A. Vela, V. Pasqualini, C. Pergent-Martini \& G. Pergent. 2008. Effects of 600 experimental reduction of light and nutrient enrichment $(\mathrm{N}$ and $\mathrm{P})$ on seagrasses: a 601 review. Aquatic Conservation: Marine and Freshwater Ecosystems. 18: 202-220.

602 Marbà N. \& C. M. Duarte. 1998. Rhizome elongation and seagrass clonal growth. Marine 603 Ecology Progress Series. 174: 269-280.

604 McNaughton, S. J., F. F. Banyikwa \& M. M. McNaughton. 1997. Promotion of the cycling of 605 diet-enhancing nutrients by African grazers. Science. 278 (5344): 1798-1800.

606 Molina-Hernández, A. L. \& B. I. van Tussenbroek. 2014. Patch dynamics and species shifts in 607 seagrass communities under moderate and high grazing pressure by green sea-turtles. 608 Marine Ecology Progress Series. 517:143-157.

609 Moran, K. L., \& K. A. Bjorndal. 2005. Simulated green turtle grazing affects structure and 610 productivity of seagrass pastures. Marine Ecology Progress Series. 305: 235-247.

611 Moran, K. L., \& K. A. Bjorndal. 2007. Simulated green turtle grazing affects nutrient 612 composition of the seagrass Thalassia testudinum. Marine Biology. 150: 1083-1092.

613 Olff, H. \& M. E. Ritchie. 1998. Effects of herbivores on grassland plant diversity. Trends in $614 \quad$ Ecology and Evolution. 13 (7): 261-265.

615 Ralph, P. J., M. J. Durako, S. Enríquez, C. J. Collier \& M. A. Doblin. 2007. Impact of light 616 limitation on seagrasses. Journal of Experimental Marine Biology and Ecology. 350: 176$617 \quad 193$.

618 Ray, B. R., M. W. Johnson, K. Cammarata, D. L. Smee. 2014. Changes in seagrass species 619 composition in Northwestern Gulf of Mexico estuaries: Effects on associated seagrass 620 fauna. PLoS ONE. 9 (9): e10. 
621 Rodríguez-Martínez, R. E., F. Ruíz-Rentería, B. van Tussenbroek, G. Barba-Santos, E. 622 Escalante-Mancera, G. Jordán-Garza \& E. Jordán-Dahlgren. 2010. Environmental state

623

624

625

626

627

628

629

630

631

632

633

634

635

636

637

638

639

640

641

642

643 and tendencies of the Puerto Morelos CARICOMP site, Mexico. Revista de Biología Tropical. 58(3): 23-43.

Smolders, A. J. P., M. Moonen, K. Zwaga, E. Lucassen, L. P. M. Lamers \& J. G. M. Roelofs. 2006. Changes in pore water chemistry of desiccating freshwater sediments with different Sulphur contents. Geoderma. 132: 372-383.

Thayer, G. W., K. A. Bjorndal, J. C. Ogden, S. L. Williams, J. C. Zieman. 1984. Role of larger herbivores in seagrass communities. Estuaries. 7: 351-376.

Touchette, B. W. \& J. M. Burkholder. 2000. Review of nitrogen and phosphorus metabolism in seagrass. Journal of Experimental Marine Biology and Ecology. 250: 133-167.

Valentine, J. F. \& J. E. Duffy. 2006. The central role of grazing in seagrass ecology. En: Larkum, A. W. D., Orth, R. J., y Duarte C. M. (Eds.). Seagrasses: Biology, ecology and conservation (pp. 463-501). The Netherlands: Springer.

van Tussenbroek, B. I. 2011. Dynamics of seagrasses and associated algae in coral reef lagoons. Hidrobiológica. 21(3): 293-310.

van Tussenbroek, B. I, J. Cortés, R. Collin, A. C. Fonseca, P. M. H. Gayle, H. M. Guzman, G. E. Jácome, R. Juman, K. H. Koltes, H. A. Oxenford, A. Rodríguez-Ramirez, J. SamperVillarreal, S. R. Smith, J. J. Tschirky \& E. Weil. 2014. Caribbean-wide, long-term study of seagrass beds reveals local variations, shifts in community structure and occasional collapse. PlosOne March 3rd 2014.

van Tussenbroek, B. I., H. A. Hernández Arana, R. E. Rodríguez-Martínez, J. Espinoza-Avalos, H. M. Canizales-Flores, C. E. González-Godoy, M. G. Barba-Santos, A. Vega-Zepeda, L. 
644

645

646

647

648

649

650

651

652

653

654

655

656

Collado-Vides. 2017. Severe impacts of brown tides caused by Sargassum spp. on nearshore Caribbean seagrass communities. Marine Pollution Bulletin 122: 272-281.

Williams, S. L. 1987. Competition between the seagrasses Thalassia testudinum and Syringodium filiforme in a Caribbean lagoon. Marine Ecology Progress Series. 35: 91-98.

Williams, S. L. 1988. Thalassia testudinum productivity and grazing by green turtles in a highly disturbed seagrass bed. Marine Biology. 98: 447-455.

Williams, S. L. 1990. Experimental studies of Caribbean seagrass bed development. Ecological Monographs. 60 (4): 449-469.

Zieman, J. C., R. L. Iverson \& J. C. Ogden. 1984. Herbivory effects on Thalassia testudinum leaf growth and nitrogen content. Marine Ecology Progress Series. 15: 151-158.

PeerJ reviewing PDF | (2019:03:35652:1:1:NEW 9 Jul 2019) 
Figure $\mathbf{1}$ (on next page)

Bar graphs displaying mean ( \pm SE) ammonium concentration in sediment pore-water as function of grazing levels.

The grazing levels significantly affected ammonium concentration in sediment $(p=0.013)$, with different letters representing significant pairwise comparisons between treatments. C Control, ST Short-term, MT Medium-term, LT Long-term, R Recovery. 


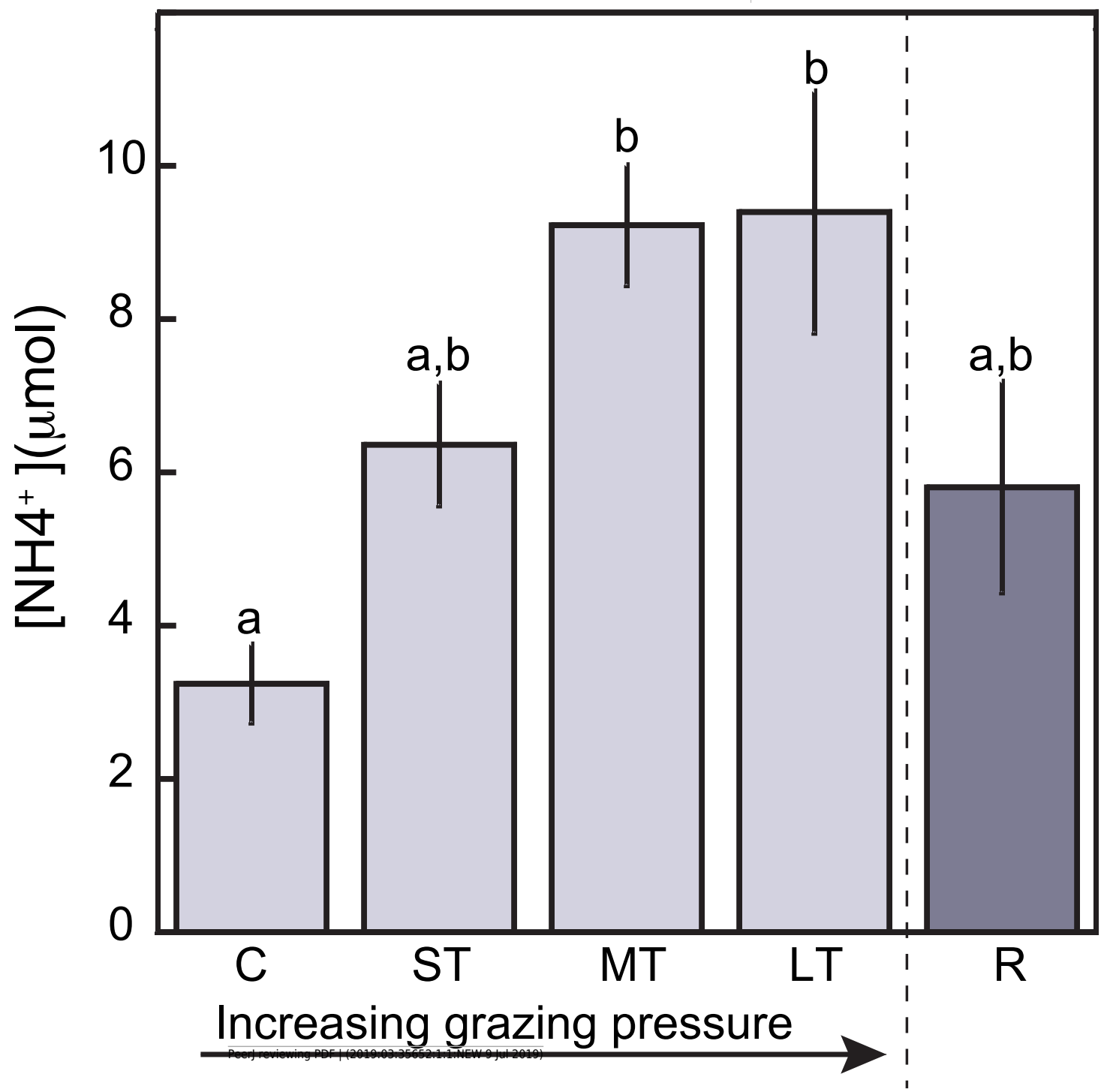


Figure 2 (on next page)

Bar graphs displaying mean ( \pm SE) total biomass (above- and below-ground).

(a) Late-successional species Thalassia testudinum and (b) early-successional species (Syringodium filiforme and rhizophytic algae), as a function of grazing levels. C Control, ST Short-term, MT Medium-term, LT Long-term, R Recovery. Note differences in Y-axis 


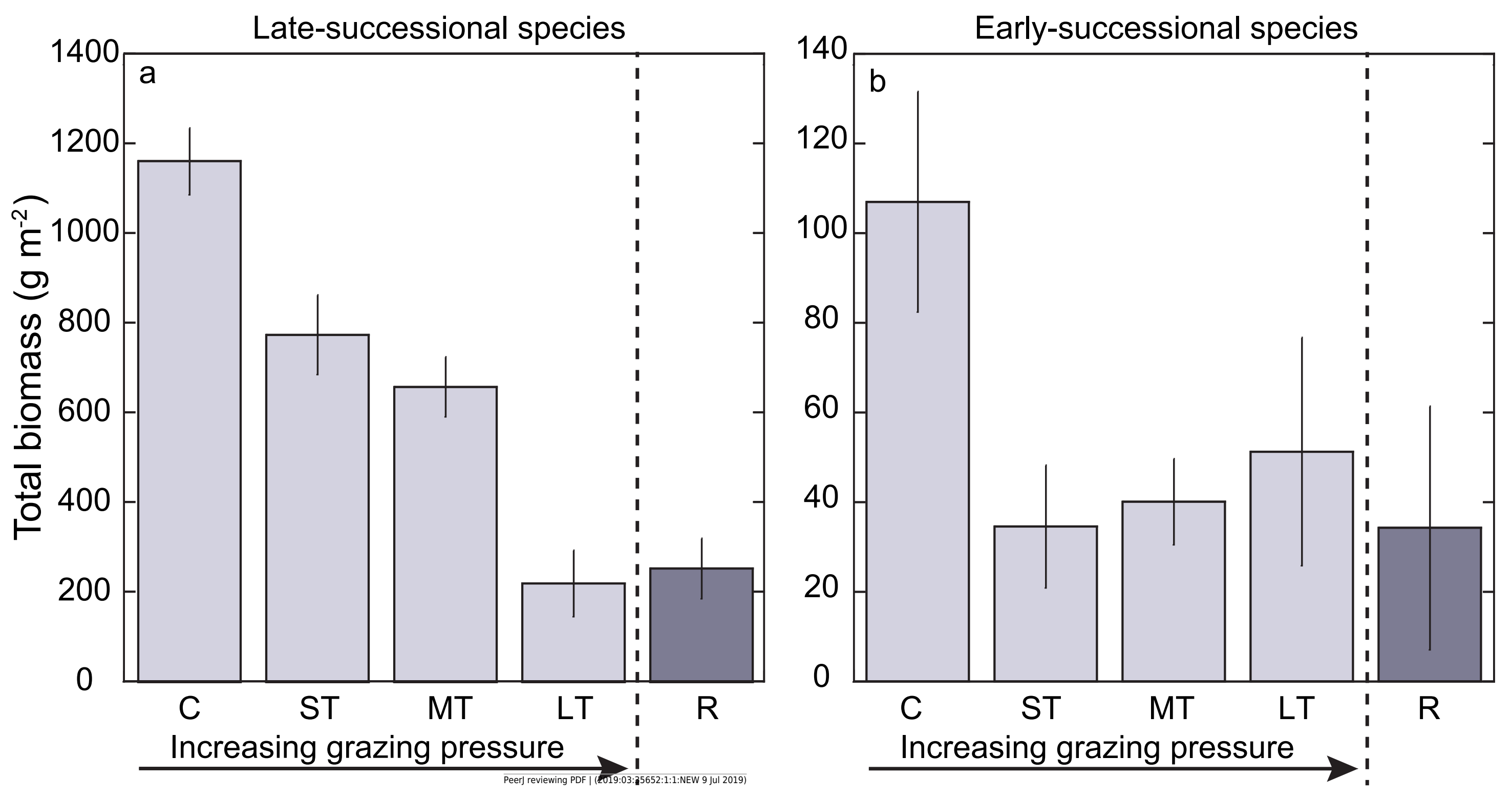


Figure 3 (on next page)

Bar graphs displaying mean ( $\pm \mathrm{SE}$ ) of the relative contribution of early-successional species (Syringodium filiforme and rhizophytic algae) to total density as function of grazing levels.

Grazing levels are C Control, ST Short-term, MT Medium-term, LT Long-term, R Recovery. 
MeerJ
Contribution of early to be reviewed
successional species

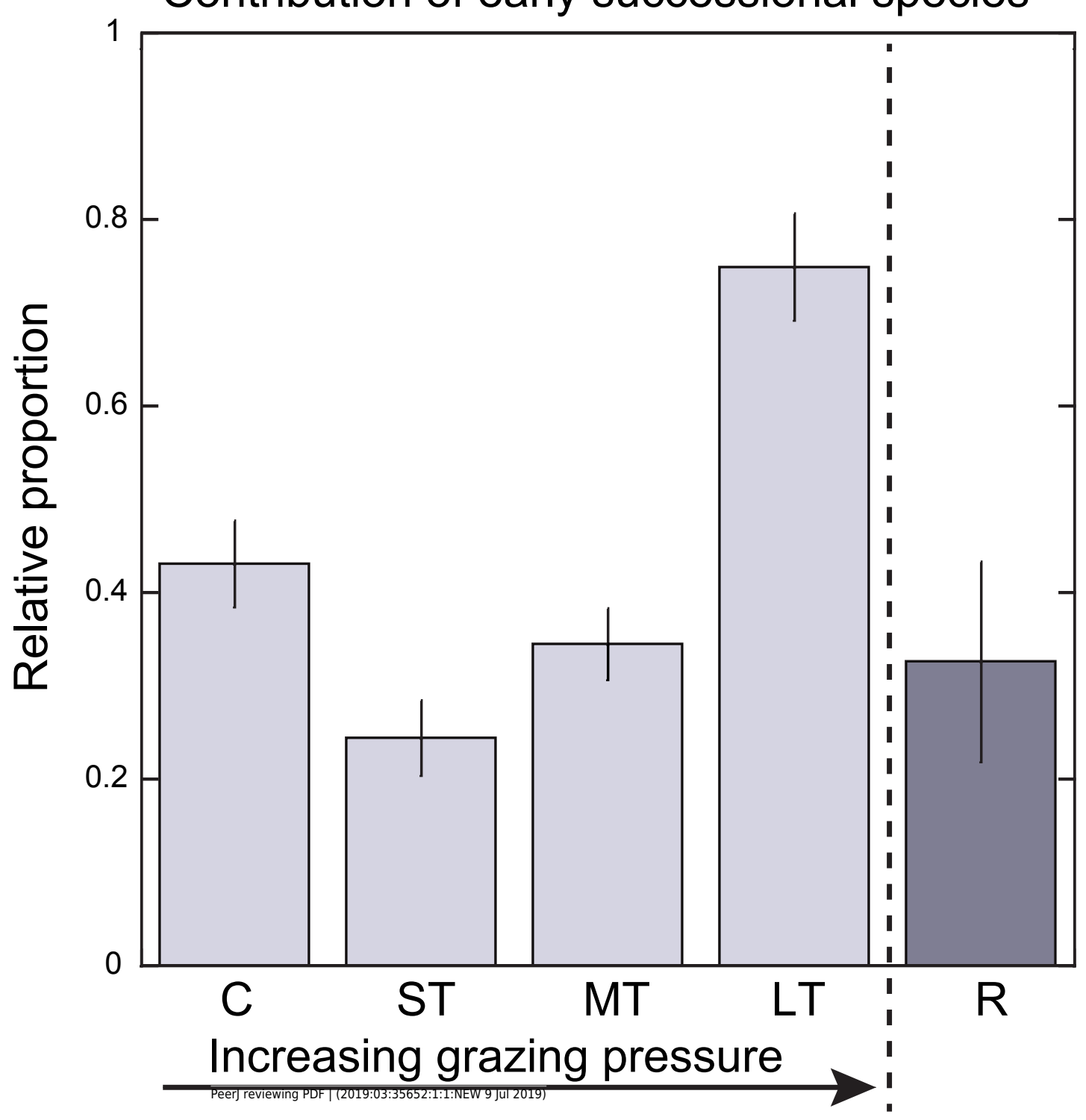


Figure 4 (on next page)

Relationship between ammonium concentration in pore-water of sediments and total biomass of Thalassia testudinum.

Control (filled circles), Short-term (open squares), Medium-term (filled diamonds), Long-term (filled squares) and Recovery (open circles). Error bars $\pm \mathrm{SE}$. 
Figure $\mathbf{5}$ (on next page)

Shift in species composition of a Caribbean seagrass community under a regime of rotational grazing, showing the principal processes involved in the transition from late seral state to earlier seral state during grazing and vice versa during recovery.

Resource in the sediment may be N, P, Fe, depending which is limiting under the prevailing conditions. Tt Thalassia testudinum, Sf Syringodium filiforme, Hw Halodule wrightii, rhiz. algae rhizophytic algae. 


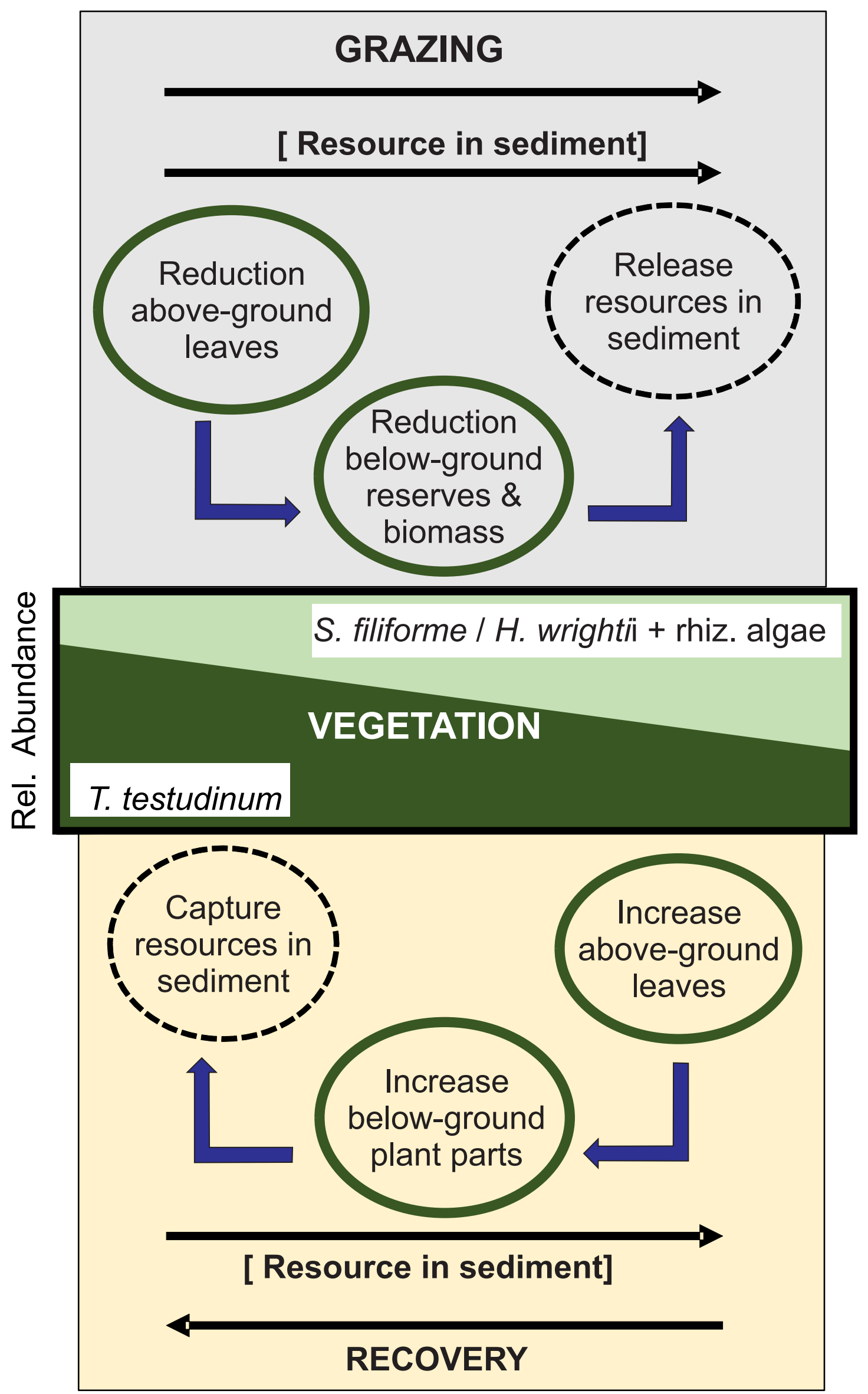




\section{Table $\mathbf{1}$ (on next page)}

Grazing levels of the experiment, with dates of start and duration of the treatments.

Recovery level was marked in June 2015 and then was undisturbed till the end of the experiment (8 months). The experiments were finished in February-March 2016. *Previously grazed patches had just been abandoned by the turtles; Molina-Hernández \& van Tussenbroek (2014) established that abandoned patches were grazed by turtles $\geq 1 \mathrm{y}$. **The Long-term grazing level does not occur naturally in patch rotational grazing because turtles do not return to abandoned patches. 
1

\begin{tabular}{llll}
\hline Previous seagrass & Experimental & Explanation & Initiation of \\
condition & clipping & & Clipping \\
\hline Ungrazed & None & Control & \\
Ungrazed & 4 months & Short-term & October 2015 \\
Ungrazed & 8 months & Medium-term & June 2015 \\
Previously grazed * & 8 months & Long-term ** & June 2015 \\
Previously grazed * & None & Recovery & \\
\hline
\end{tabular}

2

3

4 


\section{Table 2 (on next page)}

Average values ( $+\mathrm{SE})$ and results of sediment analysis.

One-way ANOVAs tested differences in the percentage of organic matter content and fine sediments (\%) among grazing levels: No grazing (Control), Short-term, Medium-term, Longterm and Recovery. Data were arcsine transformed. Different letters represent significant pairwise comparisons between the levels. 
1

\begin{tabular}{|c|c|c|c|c|c|c|c|c|}
\hline & \multirow{2}{*}{$\begin{array}{l}\text { Control } \\
\text { Mean } \pm \\
\text { SE }\end{array}$} & \multirow{2}{*}{$\begin{array}{l}\text { Short-term } \\
\text { Mean } \pm \text { SE }\end{array}$} & \multirow{2}{*}{$\begin{array}{l}\text { Medium-term } \\
\text { Mean } \pm S E\end{array}$} & \multirow{2}{*}{$\begin{array}{l}\text { Long-term } \\
\text { Mean } \pm \text { SE }\end{array}$} & \multirow{2}{*}{$\begin{array}{l}\text { Recovery } \\
\text { Mean } \pm \\
\text { SE }\end{array}$} & \multicolumn{2}{|c|}{ ANOVA } & \multirow{2}{*}{$\begin{array}{c}\text { Results } \\
\text { p }\end{array}$} \\
\hline & & & & & & df & $\mathbf{F}$ & \\
\hline $\begin{array}{l}\text { Organic } \\
\text { matter } \\
(\%)\end{array}$ & $\begin{array}{l}1.70 \\
\pm 0.32\end{array}$ & $\begin{array}{l}1.56 \\
\pm 0.34\end{array}$ & $\begin{array}{l}1.87 \\
\pm 0.33\end{array}$ & $\begin{array}{l}1.52 \\
\pm 0.34\end{array}$ & $\begin{array}{l}1.55 \\
+0.53\end{array}$ & 4 & 0.252 & 0.905 \\
\hline $\begin{array}{l}\text { Fine } \\
\text { sediments } \\
(\%)\end{array}$ & $\begin{array}{l}54.75 \\
+3.14^{\mathrm{a}}\end{array}$ & $\begin{array}{l}53.67 \\
+3.91\end{array}$ & $\begin{array}{l}41.5 \\
\pm 11.03^{\mathrm{a,c}}\end{array}$ & $\begin{array}{l}7.83 \\
+0.05^{b}\end{array}$ & $\begin{array}{l}17.90 \\
+6.27^{\mathrm{c}}\end{array}$ & 4 & 11.299 & $<0.001$ \\
\hline $\begin{array}{l}2 \\
3\end{array}$ & & & & & & & & \\
\hline
\end{tabular}




\section{Table 3(on next page)}

Nested ANOVAs used to test differences in ammonium $\left[\mathrm{NH}_{4}^{+}\right]$, phosphate $\left[\mathrm{PO}_{4}{ }^{3-}\right]$ and nitrate $\left[\mathrm{NO}_{3}^{-}\right]$concentrations $(\mu \mathrm{M})$ from sediment pore-water as a function of the grazing levels.

Grazing levels are Control $(n=18)$, Short-term $(n=20)$, Medium-term $(n=20)$, Long-term $(n=19)$ and Recovery $(n=19)$. 


\begin{tabular}{|c|c|c|c|c|c|}
\hline \multirow[b]{2}{*}{$\begin{array}{l}\text { Pore-water } \\
\text { Parameter }\end{array}$} & \multicolumn{5}{|c|}{ Nested ANOVA results } \\
\hline & SS & d.f. & MS & $\mathbf{F}$ & $\mathbf{p}$ \\
\hline \multicolumn{6}{|c|}{ Ammonium $(\boldsymbol{\mu M})$} \\
\hline Treatment & 315.375 & 4 & 87.844 & 3.398 & $<0.013$ \\
\hline Subreplicate & 1691.851 & 20 & 84.593 & 3.273 & $<0.001$ \\
\hline Residuals & 1886.948 & 73 & 25.849 & & \\
\hline \multicolumn{6}{|l|}{ Nitrate $(\mu \mathbf{M})$} \\
\hline Treatment & 0.024 & 4 & 0.006 & 0.264 & 0.900 \\
\hline Subreplicate & 0.294 & 20 & 0.015 & 0.648 & 0.862 \\
\hline Residuals & 1.657 & 73 & 0.023 & & \\
\hline \multicolumn{6}{|c|}{ Phosphate $(\mu \mathrm{M})$} \\
\hline Treatment & 0.119 & 4 & 0.030 & 0.498 & 0.738 \\
\hline Subreplicate & 1.558 & 20 & 0.078 & 0.207 & 0.207 \\
\hline Residuals & 4.311 & 72 & 0.060 & & \\
\hline
\end{tabular}

2

3

4 


\section{Table 4 (on next page)}

Average values ( $+\mathrm{SE}$ ) and one-way ANOVA results used to test differences in Thalassia testudinum nitrogen, carbon and phosphorous content in leaves (\%) and soluble carbohydrate reserves in rhizomes among grazing levels. 


\begin{tabular}{|c|c|c|c|c|c|c|c|c|c|}
\hline & & Control & $\begin{array}{l}\text { Short- } \\
\text { term }\end{array}$ & $\begin{array}{l}\text { Medium- } \\
\text { term }\end{array}$ & $\begin{array}{l}\text { Long- } \\
\text { term }\end{array}$ & Recovery & \multicolumn{3}{|c|}{ ANOVA results } \\
\hline & Sample & $\begin{array}{l}\text { Mean } \pm \\
\text { SE }\end{array}$ & $\begin{array}{l}\text { Mean } \pm \\
\text { SE }\end{array}$ & $\begin{array}{l}\text { Mean } \pm \\
\text { SE }\end{array}$ & $\begin{array}{l}\text { Mean } \pm \\
\text { SE }\end{array}$ & $\begin{array}{l}\text { Mean } \pm \\
\text { SE }\end{array}$ & df & $\mathbf{F}$ & $\mathbf{p}$ \\
\hline Leaf nitrogen & shoot & 1.65 & 2.02 & 2.00 & 2.00 & 1.94 & 4 & 7.394 & $<0.001$ \\
\hline (N) & & $\pm 0.04^{\mathrm{a}}$ & $\pm 0.06^{\mathrm{b}}$ & $\pm 0.04^{\mathrm{b}}$ & $\pm 0.04^{\mathrm{b}}$ & $\pm 0.04^{\mathrm{b}}$ & & & \\
\hline Leaf carbon & shoot & 34.34 & 34.8 & 35.69 & 35.3 & 36.13 & 4 & 1.180 & 0.351 \\
\hline (C) & & \pm 0.73 & \pm 0.69 & \pm 0.83 & \pm 0.73 & \pm 0.47 & & & \\
\hline Leaf & shoot & 20.92 & 17.3 & 16.84 & 17.63 & 18.66 & 4 & 5.511 & $<0.004$ \\
\hline $\mathrm{C}: \mathrm{N}$ ratio & & $\pm 0.81^{\mathrm{a}}$ & $\pm 0.43^{b}$ & $\pm 0.86^{\mathrm{b}}$ & $\pm 0.39^{b}$ & $\pm 0.57^{\mathrm{a}, \mathrm{b}}$ & & & \\
\hline Leaf & shoot & 18.27 & 18.79 & 20.87 & 19.84 & 20.03 & 4 & 1.059 & 0.404 \\
\hline $\mathrm{N}: \mathrm{P}$ ratio & & \pm 0.79 & \pm 1.00 & \pm 1.08 & \pm 1.35 & \pm 0.93 & & & \\
\hline Rhizome & core & 89.83 & 60.6 & 33.65 & 9.79 & 30.26 & 4 & 77.020 & $<0.001$ \\
\hline carbohydrates & & $\pm 14.41^{\mathrm{a}}$ & $\pm 6.86^{b}$ & $\pm 2.66^{c}$ & $\pm 1.72^{\mathrm{d}}$ & $\pm 4.53^{\mathrm{e}}$ & & & \\
\hline$\left(\mu \mathrm{M} \mathrm{g} \mathrm{DW}^{-1}\right)$ & & & & & & & & & \\
\hline
\end{tabular}

